\title{
Directive speech act in President Joko Widodo's speech related to handling coronavirus (Covid-19) in Indonesia (Pragmatic review)
}

\section{Desi Novita Sari}

Indonesian Language and Literature Department, Language and Arts Faculty, Universitas Negeri Semarang, Indonesia

Email: desinovitasari26@students.unnes.ac.id

\author{
Asep Purwo Yudi Utomo \\ Indonesian Language and Literature Department, Language and Arts Faculty, \\ Universitas Negeri Semarang, Indonesia \\ Email: aseppyu@mail.unnes.ac.id
}

\begin{abstract}
Knowing the type of speech act is very important to understand to see the kind of speech act and its meaning and purpose behind the utterance. The purpose of this study is to describe the types, forms, and meanings or intentions of speech acts in the president's speech related to the handling of the coronavirus, especially with pragmatic studies. The type of research used is qualitative research. This study's data source is the video source contained in the upload of an account on Youtube. The data in this study are all speech acts, which are directive speech acts. The data collection techniques used are recording, observation, observation, and note-taking. The results showed: first, the directive speech acts consist of speech acts by asking, inviting, pleading, ordering, and prohibiting. Second, the speech act is in the form of an oral form, an utterance uttered by the president in his speech regarding the coronavirus's handling, which tends to be qualitative. Third, the purpose of this directive
\end{abstract}


speech act has several meanings, namely to influence, invite, something, tell or explain something, expect attention, forbid, praise, criticize, and as a form of channeling complaints.

Keywords: Speech Act, Pragmatics, YouTube, Directive, Speech.

\section{Introduction}

Talking about the current President of Indonesia, there are many interesting things to discuss, especially in terms of pragmatics. According to Leech (1983: 1), pragmatics is the study of how language is used in communication.

This research focuses on the speech acts of a head of state, which will usually be packaged neatly, formally, and has its own goals and intentions. Especially, if he wants to convey a policy that will take into account everything, from the contents of his speech, the impact of the results, style of speech, gestures, selection of diction to be used, to speech acts are very detailed attention.

The speech act is a language activity carried out by the speaker to communicate the meaning and purpose of the speech to the interlocutor. The meaning and purpose of a speech can be understood by the interlocutor based on the context of the speech. Sudaryat (2009: 21) states that the context is the situation or setting in which communication occurs. Context can be considered as the cause and reason for a conversation or dialogue.

Speech act review is an important study in Pragmatics. This refers to Rustono's (1999: 33) presentation that "speech acts are central entities in pragmatics so that speech acts become the basis for the analysis of other pragmatic topics, such as presuppositions, implications of conversation, principles of cooperation, and principles of politeness."

The reason for the expression of speech acts is that in saying an expression, the speaker does not merely say something by saying the exorcism. In the expression of that expression, he also 'acts' on something (Purwo 1990: 19).

Speech act theory developed by experts such as Austin (1962: 151), Searle (1969: 23), and Leech (1993: 106) have placed the Directive speech act as one of the macro aspects of illocutionary acts. Illocutionary act (illocutionary act) is one of the divisions of speech acts including acts of locution and acts of perlocution. 
Verbs used in the Directive speech act are generally included in the competitive category because this verb category requires negative politeness unless the verb directive invites (to invite) is intrinsically polite. Sub-acts of speech used as markers of Directive speech act are asking or begging (to beg), ordering (to order), begging or pleading very (to request), advocating (to suggest) governing or giving orders, demanding, and prohibit.

Competitive realization of Directive speech act is the request of the speaker to the interlocutor to take certain actions or vice versa, the prohibition of the speaker to the interlocutor not to take certain actions. According to Searle (1969: 23) and Leech (1993: 104-107), the type of Directive speech act includes acts of command, requests, suggestions, and permissions. Thus, pragmatically the Directive speech act covers the intent of orders, requests, giving advice, and granting permits.

Based on the context, the form of the Directive speech act has four functions, namely (1) competitive function, (2) conflictive function, (3) convenient function, and (4) collaborative function. The competitive function is in the form of competition with social goals, the conflictive function is in conflict with social goals, and the pleasant function is in the form of positive judgment with social goals as well. Meanwhile, the function of cooperation is in the form of maintaining balance and harmony of interaction behavior in certain socio-cultural contexts.

Furthermore, Kreidler (1998: 183-194) divides the type of Directive speech act into three, namely (1) commands, (2) requests, and (3) suggestions. A command is possible if the speaker can control the interlocutor. Verbs contained in this utterance are; rule, require, disallow, and so on. Meanwhile, a request is a form of speech that states the speaker "wants" the interlocutor to take the desired action. Verbs stating requests include; begging, hoping, wanting, wanting, and so on. Furthermore, a suggestion is a speech made by speakers containing suggestions or opinions or asking others to give opinions or suggestions about something to do or not do. Verbs that include suggestions include; advising, expressing opinions or suggestions, suggesting, recommending, reminding, and so on.

Based on the background, the problem in research can be formulated, namely (1) What are the types of directive speech acts that exist in the president's speech about handling Covid-19 in Indonesia?, (2) What are the speech strategies needed by President Jokowi when giving a speech? 
The purpose of this study is (1) to describe the types of directive speech acts contained in the President's speech regarding the handling of Covid-19 in Indonesia, (2) to describe what speech strategies contained in the President's speech regarding the handling of Covid-19 in Indonesia.

\section{Literature Review}

Speech acts are part of pragmatics. Speech act is the utterance of a sentence to state that the hearing of the speaker is known. Speech atcs are utterances made as part of social interaction. According to Leoni (in Sumarsono, and Paina Partama, 2010: 329-330) speech acts are part of speech events, and speech events are part of speech situations. Every speech event is limited to activities, or aspects of activities that are directly regulated by the norms or norms for the speaker.

Thus, action is a characteristic of speech in communication. It is assumed that in realizing speech or discourse, someone does something, namely the performance of the action. Speech in the form of action performance is called performative speech, namely speech that is intended to carry out an action.

Speech act is an individual symptom, is psychological in nature, and is determined by the speaker's language ability in dealing with certain situations. Speech acts are focused on the meaning or meaning of acts, while speech events are focused more on the purpose of the events. In this speech act, a speech event is carried out by the speaker to the speech partner in order to convey communication. Austin (in Subyakto, 1992: 33) emphasizes speech acts in terms of the speaker. Sentences in the formal form of 10 questions provide information and can also function to carry out a speech act performed by the speaker.

From the description above, it can be concluded that speech acts are the activities of a person using language to speech partners in order to communicate something. What is communicated meaning can not only be understood based on the use of language in the speech but also determined by the aspects of communication in a comprehensive manner, including the situational aspects of communication. Teachers and students are components of holistic teaching. Between teachers and students influence each other and encourage each other to carry out one activity with another. Basically, students are a determining element in holistic learning. 


\section{Methods}

This research is qualitative which emphasizes the problem of process and meaning (Sutopo, 1996: 38). The study is in the form of qualitative, where research findings will be described qualitatively in the form of words and not mathematical or statistical numbers (Lindlof, 1994: 21). The strategy developed in this research is a case study.

Based on this type of research, the research was conducted to describe the directive speech acts in uploads on YouTube accounts. The focus of this study is the use of directive speech acts in President Joko Widodo's speech regarding the handling of corona virus cases (Covid-19) in Indonesia. This research was designed in a descriptive qualitative manner. The characteristic of descriptive qualitative research is the source of data in the form of natural settings.

The data source in this study is an oral source in the form of a spoken language contained in the upload of a YouTube account in the form of video upload. The data in this study in the form of the whole directive speech acts used in an oral speech on a YouTube account.

The informant who is the source of this research data is President Joko Widodo in the government environment which occupies the top position in the organizational structure of a country. The research data in the form of speech act lingual units used by the leader in his speech regarding the handling of corona virus cases (Covid-19), namely when giving speeches, counseling, directing, and guiding, and conveying information, opinions and/or discussing and giving speeches to the community Indonesia. The data collection methods used are the recording technique, observation technique, observation technique, and note-taking technique.

\section{Results and Discussion}

As stated by Searle (1976) that the linguistic unit in communication is not just a symbol, word, or sentence, but all of this refers more to the performance of the speech act (performance of the speech act). So, language is not only a display of concepts that have in mind but how to produce an understanding that is followed by an action. In the president's speech, speech by speech is not just spoken but has a purpose that is understood by the audience and has the power to bring an action.

The research began with data collection, which is in upload on a YouTube 
account. The results of this collection are the research data and are further discussed by analyzing them one by one.

Research on speech acts has been done a lot. The literature review in this study refers to the 2015 Yusrita Yanti's thesis entitled "The Model of Directive and Expressive Speech Acts of President Jokowi's inauguration Speech," Arnola Dwika Ramanda, Ermanto, Novia Juita's thesis entitled "Illocution Speech Acts on President Jokowi's state speech on 14th August 2015" and the Septin Ariyani's 2017 thesis entitled" The Form and Function of Directive Speech Acts in the Indonesian Language Learning Process "and Nur Rachmi Widyarini's 2016 thesis entitled" Analysis of Directive, Expressive, and Commissive Speech Acts in the Speech Texts of Class X Student Essays Muhammadiyah 2 Blora Vocational High School". In these previous studies, there were similarities in the data used, namely by using a video and transcript of a president's speech and the results of their research discussed speech acts. But in this research, the study focuses on directive speech acts.

In Jokowi's state address on handling the Covid-19 case in Indonesia, Jokowi used directive speech acts, namely:

1. The Form of Directive Speech Act "President's Speech Regarding Handling of Corona Virus (Covid-19) in Indonesia."

The directive speech act is sometimes also called the impisiotive speech act is the speech act intended by the speaker so that the interlocutor performs the action mentioned in the speech. Directive is a type of speech act used by a speaker to get someone else to do something. This type of speech act states what the speaker wants. These speech acts include; ask, invite, plead, govern, and forbid including the type of directive speech acts.

The directive speech acts are part of the illocutionary act. Blum-kulka (through prayitno, 2011: 32) states that to measure directive speech acts, namely the Nine modes are to use the form of imperative, performative explicit, performative pager, statement of necessity, statement of desire, statement of suggestion, statement of strong question questions, and subtle cues. The directive speech act is the type of speech act used by the speaker to get someone else to do something. This speech act type states that the directive act acts across the message. This means that language can be used to influence others. Both his emotions, his feelings, and his behavior. The same thing was expressed by Widada (1999: 3) which states that directive communication is a speech or utterance that contains that other people want to take action in accordance 
with what is desired by the speaker. From some of the opinions above, it can be concluded that the directive speech act is a form of speech that has the intention for the speech partner to do something as told by the speaker.

The following are forms of directive speech acts that I can catch in President Joko Widodo's speech in handling the corona virus (Covid-19) in Indonesia, namely:

\subsection{Request (to beg)}

The form of request directive speech acts according to Prayitno (2010: 51) states that the demand directive is a speech that aims to request and expect the interlocutor to be given something to become a reality as requested by the speaker. In the request speech act, there is a function of asking and hoping. The directive speech acts have the following functions; asking, hoping, begging, and offering. The requesting function is to express the utterance to the speech partner, so that the speaker gets something. The data that shows the above explanation include:

a. "I also ask the Regional Head to support this policy and carry out adequate policies in the regions."

The word "ask" in data 1 above shows that the speaker expresses the request statement. A speaker conveys his message through the text of the speech above marked by the appearance of the word ask as a sign that the sentence is a request sentence. The speech is a direct speech because the instructor asks the interlocutor directly, namely to the Regional Head to support President Joko Widodo's policies.

b. "Finally, to all Indonesian people, I ask to remain calm, not panic, and stay productive by increasing awareness so that the spread of Covid-19 can be blocked and stopped."

The word "ask" in data 2 above shows that the speaker expresses the request statement. A speaker conveys his message through the text of the speech above marked by the appearance of the word ask as a sign that the sentence is a request sentence. The speech is a direct speech because the speaker asks directly to the interlocutor that is to all the people of Indonesia to remain calm and increase awareness so that the spread of Covid-19 can be inhibited.

c. "I ask all Governors and Regents and Mayors to continue monitoring the condition of the area and continue to consult with medical experts in examining the situation." 
The word "ask" in data 3 above shows that the speaker expresses the request statement. A speaker conveys his message through the text of the speech above marked by the appearance of the word ask as a sign that the sentence is a request sentence. The speech is a direct speech because the speaker asks directly to the interlocutor, namely to all Governors and Regents and Mayors to continue monitoring the condition of the area and continue to consult with medical experts about Covid-19.

\subsection{Inviting}

The form of invitation directive speech act according to Prayitno (2010: 51) states that the directive invitation implies that the speaker invites the interlocutor to do something as stated by the speaker through joint speech. In the directive speech act of invitation, there are functions such as: inviting, seducing, and encouraging. The directive speech act has a function, among others; invite, encourage, seduce, support, push, demand, challenge, collect, and target. The inviting function is to express the utterance to the speech partner, so that the speech partner participates or does something as the speaker has said.

The encouraging function is to express utterances which contain an urgent or compelling intention to the speech partner, so that the speech partner is willing to do something as the speaker says. The function of seducing is to express utterances that contain the intention of persuading or encouraging with compassion so that the speech partner does something as told by the speaker. The support function is to express speech that means intending to ask the partner to do something as told by speaker. The urgent function is to express speech that has the intention of strongly encouraging the speech partner, so that the speech partner does something about what the speaker has said. The demanding function is to express speech that contains the intention to force hard on the speech partner, so that the speech partner does something as told by the speaker. The challenging function is to express speech that contains the intention of forcibly inviting the speech partner, so that the speech partner does something as spoken by the speaker. The billing function is to express speech that contains the purpose of demanding to the speech partner subtly, so that the speech partner fulfills its obligations in things to do activities. The target function is to express the utterances that must be done by the speech partner. The data that shows the above explanation include:

a. "Based on the emergency status of the area, the ranks of the Local Government are assisted by the ranks of the TNI (The Indonesian National Armed Forces) and POLRI (the Indonesian National Police) as well as 
support from the central government to continue to take effective and efficient steps in dealing with the spread and impact of Covid-19."

The data 4 above shows that the speaker expresses the invitation speech. The utterances are direct speeches to the interlocutor namely to the ranks of TNI and POLRI as well as support from the central government to continue to take effective and efficient steps in dealing with the spread and impact of Covid-19.

b. "With this condition, it's time we work from home, learn from home, worship at home. This is the time to work together, help one another, and unite, work together, we want this to become a community movement so that the Covid-19 problem can be handled optimally. "

Data 5 above shows that the speaker expresses the invitation speech. The speech is a direct speech to the interlocutor, namely to all Indonesian people to work together to deal with the COVID-19 problem in Indonesia.

c. "Increasing the Covid-19 infection testing and treatment services to the fullest, by utilizing the capabilities of Regional Hospitals, and working with private hospitals, as well as research and higher education institutions, recommended by the Ministry of Health."

Data 6 above shows that the speaker expresses the invitation speech. The speech is a direct speech to the interlocutor, namely to the entire health community to improve Covid-19 infection testing services and maximum treatment.

\subsection{Request (to request)}

The requesting speech act is the speech act that politely asks the interlocutor to do something the speaker wants. Speeches asking the President in his speech are as follows:

"Then, continue to consult with the National Agency for Disaster Management to determine the status of an area whether in emergency alert or emergency response of non-natural disaster."

Data 7 above shows that the speaker revealed the requesting statement. The speech is a direct speech delivered by the President in his speech with the interlocutor, namely to the National Agency for Disaster Management to determine the status of the emergency alert or emergency response of nonnatural disaster. 


\subsection{Govern}

The form of directive speech acts according to Prayitno (2010:51) states that the directive command is words that intend to instruct the interlocutor to do something. In the type of speech acts of command there are functions of ordering, telling, instructing, mandating, instructing, coercing, and borrowing. The data showing the explanation above are:

a. "I have instructed the Minister of Health and relevant ministries to increase extra steps in dealing with Covid-19's global pandemic.”

The word "instructed" in data 8 above shows that the speaker expresses the command speech. A speaker conveys his message through the text of the speech above marked by the appearance of the word instructed as a sign that the sentence is a command sentence. The speech is a direct speech because the speaker asks directly from the interlocutor, namely to the Minister of Health and related ministries to increase the extra step in dealing with Covid-19.

b. "Making a policy about the learning process from home for students and college students."

In data 9 above it shows that the speaker expresses the command speech. The speech is a direct speech delivered by the President in his speech with the interlocutor, namely to all teaching and learning activities at school and in higher education in Indonesia, it is turned into learning at home.

c. "Making a policy about some ASN (State Civil Apparatuses) can work at home using online interaction, while prioritizing excellent service to the community."

In the data 10 above shows that the speaker expresses the command statement. The speech is a direct speech delivered by the President in his speech with the interlocutor, namely to the government to make policies regarding the State Civil Apparatus so that some can work at home using online interaction.

d. "I have ordered to provide adequate budget support to be used effectively and efficiently."

The word "ordered" in data 11 above shows that the speaker expresses the command speech. A speaker conveys his message through the text of the speech above marked by the appearance of the word ordered as a sign that the sentence is a command sentence. The speech is a direct 
speech because the speaker asks directly to the interlocutor, namely to the Local Government to provide budget support provided by the Central Government.

\subsection{Prohibit}

The form of directive speech acts according to Prayitno (2010: 51) states that a prohibition is an act of language that aims to make the interlocutor not allowed at all or be prohibited from doing anything. In the prohibition directive speech act, there is a function of prohibiting and preventing. The directive speech acts have the following functions; prohibit and prevent. The prohibiting function is to express speech that contains the intention of instructing the speech partner not to do something or not allowing to do something. The function of preventing is to express speech that contains the intention of holding the speech partner, so that the speech partner does not do something. The data that shows the above explanation include:

a. " Postpone activities involving many participants."

Data 12 above shows that the speaker expresses the prohibited speech. The speech is a direct speech delivered by the President in his speech with the interlocutor, namely to the Indonesian people to postpone activities involving many people to reduce Covid-19 increase.

Based on the form of directive speech acts that have been spoken by Prayitno, and Ruhardi, the author makes indicators of the form of directive speech acts are as follows:

Table Indicator Forms of Directives Speech Acts

\begin{tabular}{|c|c|c|}
\hline No & $\begin{array}{c}\text { Form of } \\
\text { Directive } \\
\text { Speech Act }\end{array}$ & Indicator \\
\hline 1. & Command & $\begin{array}{l}\text { a) Speech means to order to do something. } \\
\text { b) Use the word govern, command. }\end{array}$ \\
\hline 2. & Demand & $\begin{array}{l}\text { a) Speech contains the purpose of the request or } \\
\text { act of asking the speech partner. } \\
\text { b) Using the word ask. }\end{array}$ \\
\hline 3. & Invitation & $\begin{array}{l}\text { Speech intends to invite or encourage the interlocutor } \\
\text { to do something. }\end{array}$ \\
\hline 4 & Prohibition & $\begin{array}{l}\text { Speech means an order that forbids the speech partner } \\
\text { to do or do something. }\end{array}$ \\
\hline 5 & Ask/request & Speech intends to ask for a request to do something. \\
\hline
\end{tabular}


b. Speech Strategy

From the results of the study, the strategy of speaking was found, namely:

1) A straight forward strategy without further ado

a) "This is the time to work together, help one another, and unite, work together, we want this to become a community movement so that the problem of Covid-19 can be handled optimally."

In this example, the speaker said that it was time for the community to work together, help one another, and unite with each other, mutual cooperation. The speech act is a straightforward speech strategy. In the speech above, the speaker states that the community must work together to fight the co-19 pandemic in Indonesia so that it can quickly disappear from the face of the earth, especially in Indonesia.

b) "As a large country and an archipelagic state, the level of the spread of Covid-19 has varying degrees between regions."

In this example, the speaker said that Indonesia is a big country and an archipelagic state. The speech act is a straightforward speech strategy characterized by a big country and an archipelagic state. In the speech above, the speaker states that Indonesia is a large country and an archipelagic state, so the level of the spread of Covid-19 varies greatly in each region in Indonesia.

2) Continuous Speech Strategy with Negative politeness pleasantry (BBKN)

- "AssalamualaikumWarrohmatullahiWabarokatuh,

Good afternoon, Greetings to all of us, Om Swastiastu, NamoBuddhaya, Greetings of Virtue."

In this example, the speaker says greetings to all religious people. The following examples include a strategy of speaking with small politeness pleasantries (expressing respect). The speech was made by the President to all Indonesian people. The use of the reasons Assalamu'alaikumWarahmatullahiWabarakatuh, Peace of Peace to us all, Om Swastiastu, NamoBuddhaya, Greetings of Virtue. The speech made the listener (all Indonesian people) happy and respected by the speaker.

3) Continuous Speech Strategy with Positive politeness pleasantries (BBKP) 
- "Ladies and Gentlemen and the fellow countrymen,"

In this example, the speaker involves the speaker by greeting. The example speech acts include speech strategies with small politeness pleasantries. Speech delivered by a President to the listener is to say that all groups whether father or mother who are young and old are one nation and one homeland, namely Indonesia.

From President Jokowi's speech about the handling of Covid-19 in Indonesia, it can be interpreted that Jokowi uses directive speech acts so that the public can accept the decision that has been requested by the speaker, Jokowi. The directive speech act in this speech contained no order that had to be received by the public so that the handling of Covid-19 was immediately carried out. So Jokowi as the head of state is entitled and has the power to issue a policy that must be carried out by the people. Therefore, the community as the recipient of the policy has no other choice. In this case, Jokowi as the head of state accepts state officials or the government and the public in order to be able to take appropriate policies on welfare and health for the people of Indonesia.

\section{Conclusion}

Jokowi's presidential states when delivering the handling of the Covid-19 case in Indonesia used a type of directive speech act that demanded responsibility from his interlocutors (officials and also the public) to understand the situation being faced by the Indonesian people. From this analysis, the researcher found that in delivering his presidential states, Jokowi used directive speech acts with classification: asking for 3 times, asking for 3 times, asking for 1 time, ordering for 4 times, and prohibiting for 1 time. Based on the findings, it can be concluded that Jokowi's directive speech acts, many of them are commanding. The form of directive speech acts according to Prayitno (2010: 51) states that the directive commands are words that intend to instruct the interlocutors to do something. Thus, the government ordered all Indonesian people to obey the appeal made. The researcher also found Jokowi's speech act strategies in his speech about handling Covid-19 with the classification: speaking without pleasantries for 2 times, speaking with positive politeness pleasantries for 1 time, and speaking with negative politeness pleasantries for 1 time. It can be concluded that the speech act strategy that tends to be used in the speech acts of President Jokowi's speech about Covid-19 is to speak without further ado. 
Through the results of this study, the author suggests to students, especially students of the Indonesian Language and Literature Department so that they want to research speech acts in speeches of officials in Indonesia. Suggestions for further research is in analyzing directive speech acts in a speech can be assessed using Grice's implicative analysis, excised, and maxims that are useful for discussing deeper findings regarding this pragmatic study.

\section{References}

Ariyani, S., \& Rahmawati, L. E. (2017). Bentuk dan fungsi tindak tutur direktif dalam proses pembelajaran bahasa Indonesia (Doctoral dissertation, Universitas Muhammadiyah Surakarta).

Djatmika. (2016). Mengenal pragmatik yuk!? Yogyakarta: Pustaka Pelajar.

Faidah, N., Karim, A., \& Harisah, S. Representasi kekuasaan tindak tutur direktif dalam talk show Indonesia Lawyers Club di TV ONE representation of power in directive speaking actions on Indonesia Lawyer Club Talk Show TV One. BAHASANTODEA, 5(4), 142-152.

Fitriah, F., \& Fitriani, S. S. (2017). Analisis tindak tutur dalam Novel Marwah di Ujung Bara karya RH Fitriadi. Master Bahasa, 5(1), 51-62.

Huri, T. (2014). Analisis peristiwa tutur direktif kajian ceramah KH Syairozy. Artikel diunduh dari http://lughotudhod.blogspot.co.id/2014/01/ analisis-peristiwa-tutur-direktif.html

Ilmiah, N., \& Affandy, A. N. (2018). Tindak tutur direktif kampanye calon Gubernur DKI Jakarta 2016. Stilistika: Jurnal Pendidikan Bahasa dan Sastra, 10(2).

Komara, C. (2018). Analisis struktur lexical blend nama produk waralaba Indonesia. Konferensi Linguistik Tahunan Atma Jaya 13.

Kusumaningrum, F.(2018). Tindak tuturdalam pidato pasrah tinampi pernikahan masyarakat Jawa: Sebuah Kajian Sosiopragmatik. Etnolingual, 2(2).

Nuramila. (2019). Tindak tutur bahasa Indonesia dalam unggahan media sosial Instagram @Liputan6 (Kajian pragmatik). Tesis, Universitas Negeri Makassar.

Prayitno, H. J. (2009). Perilaku tindak tutur berbahasa pemimpin dalam wacana rapat dinas: Kajian pragmatik dengan pendekatan jender.

Rachman. (2017). Tindak tutur dalam proses belajar-mengajar pada taman 
kanak-kanak Dharma Wanita Kelurahan Wapunto Kecamatan Duruka Kabupaten Muna (Kajian pragmatik). Jurnal Humanika, 3(15).

Rahardi, K. (2003). Berkenalan dengan ilmu bahasa pragmatik. Malang: Dioma.

Ramanda, A. D., Ermanto, E., \& Juita, N. (2017). Tindak tutur ilokusi pada pidato kenegaraan Presiden Jokowi tanggal 14 Agustus 2015. Bahasa dan Sastra, 5(1), 11-23.

Rustono. (1999). Pokok-pokok pragmatik. Semarang: CV IKIP semarang Press.

Saputri, A., Juita, N., \& Ngusman, N. (2014). Tindak tutur direktif dalam iklan katu perdana GSM. Jurnal Bahasa dan Sastra, 2(2), 11-28.

Widyarini, N. R., \& Sabardila, A. (2017). Analisis tindak tutur direktif, ekspresif, dan komisif pada teks pidato karangan siswa kelas X SMK 2 Muhammadiyah Blora. Fakultas Keguruan dan Ilmu Pendidikan, Universitas Muhammadiyah Surakarta.

Yahya, I. K. (2013). Tindak tutur direktif dalam interaksi belajar mengajar mata pelajaran Bahasa dan sastra Indonesia di SMA Negeri 1 Mlati Sleman Yogyakarta. Universitas Negeri Yogyakarta.

Yani, M. Kajian pragmatik terhadap tindak tutur direktif guru SMA dalam kegiatan belajar mengajar di kelas. Prosiding Prasasti, 114-119.

Yanti, Y. (2001). Tindak tutur maaf dalam bahasa Indonesia di kalangan penutur Minangkabau. Linguistik Indonesia 19(1), 93-104.

Youtube video of Viva.com account with link: https://m.youtube.com/ watch? feature $=$ youtu. $b e \& v=l$ pqo-eROoc

Yule, G. (2014). Pragmatik. Terjemahan Indah Fajar Wahyuni. Yogyakarta: Pustaka Pelajar. 1996. 
Journal of Social Studies (JSS), Volume 16, Number 1, 2020: 35-50 